\title{
輝度画像を利用したブラインド制御用遮光要否判定方法の研究 STUDY ON EVALUATION METHOD OF SOLAR SHADING FOR BLIND CONTROL BASED ON LUMINANCE IMAGES
}

\author{
小島義包*，中村芳樹**，加藤 洋子***, \\ 大木 知佳子 $* * * *$, 矢 部 周子 $* * * *$, 金谷末子****** \\ Yoshikane KOJIMA, Yoshiki NAKAMURA, Yoko KATO, \\ Chikako OHKI, Chikako YABE and Sueko KANAYA
}

\begin{abstract}
For the saving energy of the illumination, it is necessary to use day light effectively. In general, office has only side window to get day light and Venetian blinds are installed in the window for solar shading. In the automatic blind control system installed at the large scale building, slats of blind are uniformly controlled by illuminance censor fixed on the top of the building. We devised technique to detect not only the direct sunlight but also the dazzling borrowed light from adjacency building based on a luminance image provided with a CCD camera for the purpose of the development of the higher precise judgment of solar shading. We built the system which could perform shading immediately at the time of the detection and introduced it into the actual work place.
\end{abstract}

Here, we report a detection method and an experimental data of the precision of the system.

Keymards:Luminance image, Blind control, Solar shading, Contrast, Filtering , 輝度画像，ブラインド制御，日射遮蔽，コントラスト，フィルタリング

\section{1. はじめに}

国は 2014 年 4 月に閣議決定した「エネルギー基本計画」におい て, 新築公共建築物等は 2020 年までに, 新築建築物は 2030 年まで に平均で ZEB（ネット・ゼロ・エネルギー・ビル）化を実現するこ とを目指すとしている。ZEBの概念は，建築・設備の種々の省エネ ルギー技術を組み合わせて大幅な省エネルギー化を図ったうえで, 太陽光発電などのような再生可能エネルギーの利用により, 見かけ 上のビルのエネルギー消費量をゼロとするものである。ZEB 化を実 現するためには，照明分野においても，徹底した省エネルギーが求 められており, 高効率な照明器具や各種センサによる照明制御の採 用のほか，自然光の有効活用がキーと考えられる。

近年，室内環境の快適性に関して多くの研究がなされており，自 然光についても知的生産性や心地よさを高める効果等の生理的, 心 理的効果も報告されている 1)-3)。また, オフィスにおいては, 従業 員の健康増進が企業価値につながる経営課題と捉える, いわゆる, 健康経営への取り組みが注目されている。建物を使う人の健康や幸 福（Well-being）を考えた環境建築が要求され始めており，自然光 の享受も重要な要素とされている。このように，建築物における自 然光利用は, 省エネルギーと健康・快適の両側面から求められるよ
うになった。

オフィスビルにおける執務室への採光手法は，側空が一般的であ る。側空の多くは，日射遮蔽のために羽根板（スラット）が水平の 横型ブラインド (ベネチアンブラインド) が設置されている。近年, ブラインドの昇降高さやスラット角度を自動制御する方式の採用が 増加している。多くの自動制御は，屋上に設置したセンサ情報を基 に直射日光の状態の判断を行うことによって，方位毎に一律に行わ れる。現在, 実用化されている遮光要否判定は, 日射量や照度を用 いて行われている。この場合，一定の閾值では太陽高度など条件の 違いによって判定誤差が出ると報告されている4)。また， CCD カメ ラによって撮影された天空画像を利用した遮光要否判定方法が報告 されている5)。ここでは，天空に向けて設置した CCD カメラ画像 を基に，最大輝度を示す地点を太陽位置として，太陽部分と周辺部 分の輝度差と設定した閾值の大小関係によって遮光判定が行われて いる。いずれも，建物屋上に設置されたセンサによって，直射日光 のみを検出することを目的としたものである。

ブラインドの開放可能な時間を長くすることは省エネルギー性と 眺望性を向上することができること ${ }^{6)}$ から，空面毎の遮光要否判断 が今後，重要になると考えられる。特に，都市部においては，周辺

\footnotetext{
本論文は，参考文献 15)-19)の内容に新たな実験結果を加筆，修正を加えたものである。

(株)大林組・東京工業大総合理工学研究科博士後期課程 - 工修

** 東京工業大学環境・社会理工学院建築学系 教授・工博

*** 東京工業大学環境 · 社会理工学院建築学系 博士後期課程 $\cdot$ 工修

$* * * * \quad$ (株)大林組

$* * * * *$ (株)大林組 工修

****** (株)ビジュアル・テクノロジー研究所 丁博
}

Obayashi Corporation, M. Eng.

Prof., Tokyo Institute of Technology, Dr. Eng.

Grad. Student, Dept. of Architecture and Building Engineering, School of

Environment and Society, Tokyo Institute of Technology, M. Eng.

Obayashi Corporation

Obayashi Corporation, M. Eng.

Visual Technology Laboratory Inc., Dr. Eng. 
建物によって直射日光が遮られる場合も多く, 屋上に設置したセン サだけでは, 適切な自動制御が難しくなっている。また, 近年, ガ ラスを外装材とした建築物や太陽光発電パネルの設置が増加してお り，建築物からの眩しい反射光による光害の事例も報告されている 7)。反射光の入射により, グレアの発生, パソコン画面への映り込 み, 集中度の低下など, 生産性や快適性を損ねることが挙げられて いる。これまでのブライン制御には, 反射光を検出し, 遮光制御す る事例はなく, 今後は, 室内に入射すると, グレアや熱感となる可 能性のある反射光や直射日光を検出し, 確実に遮光することができ る, 新たな遮光要否判定方法の研究が必要と考えた。

\section{2. 本研究の目的と目標とするブラインド制御}

本研究の目的は, CCD カメラの画像を利用して, 空面から見える 対向建物による影の影響, 周辺建物からの反射光などを含めて評価 できる, ブラインドの遮光要否判定方法の実用性を明らかにするこ とである。本研究では, グレアを発生する可能性のある直射光や反 射光を検出する方法を検討し, 空面のグレア評価は今後の研究課題 としている。

図 1 に目標とするブラインド制御の動作を示す。空面とブライン ドの間に CCD カメラを屋外に向けて設置する。連続空を持つよう な建物外装材の場合, 一般的に空面とブラインドの間には $200 \mathrm{~mm}$ 程度の空間があることから, CCD カメラをこの位置に設けることが 可能である。この CCD カメラで生成する屋外輝度画像を基に, 遮 光要否判定を行う。空面に設置することで, 当該空面に入射する直 射光や周辺建物からの反射光を検出することができ, 精度の高い遮 光制御が実現できる可能性がある。また, 建物の影になっている時 間帯は, ブラインドを開放することができ, 眺望と採光をより多く 得ることが可能である。

輝度分布の測定等, CCD カメラの光環境評価への応用例はこれま

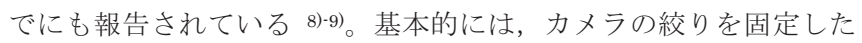
状態で, 異なる露光時間（シャッタースピード）の画像データを重 初合わせることにより輝度画像が生成できる。この輝度合成には, 数十秒を要し, ブラインド制御に利用する場合, 急な日射に応答寸 ることができないと考えられた。そこで, 本研究では制御の高速化 のために, 単一のシャッタースピードで生成する輝度画像を基に, 直射光や反射光の局所的な高輝度部分を検出する方法を検討し, そ の実用性について実証実験を行った。

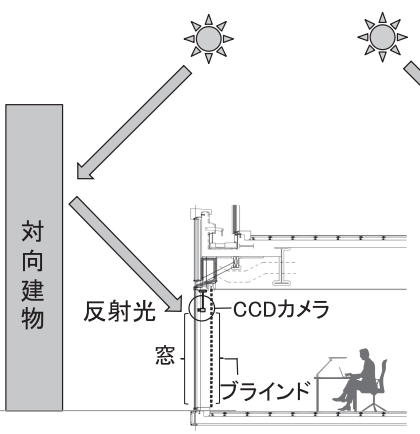

(a) 反射光の検出時 (閉)

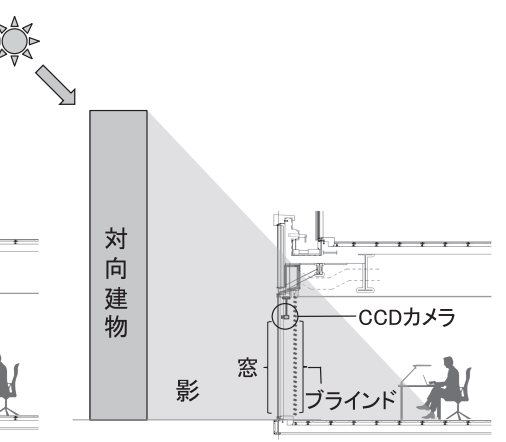

（b）周辺建物の影になる時 (開) 図 1 遮光判定によるブラインド制御の動作

\section{3. 輝度コントラストによる遮光要否判定方法}

\section{1 CCD カメラによる高輝度測定方法}

使用する CCD カメラとレンズの仕様を表 1 に, 分光感度を図 2 に示す。今回，1 台のカメラで広範囲に測定するために，魚眼レン ズを採用した。投影方式は, 照明制御にも利用することを考慮して, 撮影した画像を平面化した際にも歪夕の少ない画像が得られるよう に，等距離射影方式を採用した。

このカメラが測定可能な輝度の範囲は， $80,000 \mathrm{~cd} / \mathrm{m}^{2}$ 以下である ため，屋外で太陽のような高い輝度を撮影した場合，スミア（白飛 び）やゴーストが生じ，正しい值を測定することができない。この ため, 今回, 高い輝度も測定できるようにカメラにフィルタを設置 することを検討した。

表 1 CCD カメラとレンズの仕様

\begin{tabular}{|l|l|}
\hline 受光素子 & CCDイメージセンサ（モノクロ） \\
\hline 有効画像画素数 & $2456(\mathrm{H}) \times 2058(\mathrm{~V})$ \\
\hline フレームレート & $15 \mathrm{fps}$ \\
\hline 絞り範囲 & $\mathrm{F} 1.4-\mathrm{F} 16(\mathrm{~F} 16$ 固定で使用 $)$ \\
\hline 画角 & $185^{\circ} \quad(\mathrm{H}) \times 185^{\circ} \quad(\mathrm{V})$ \\
\hline
\end{tabular}

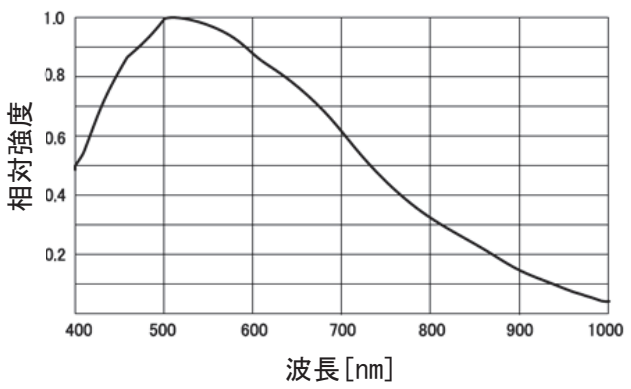

図 2 CCD カメラの分光感度 ${ }^{10)}$

フィルタは, 図 3 に示寸分光透過率を持つ ND (Neutral Density) フィルタ（シグマ光機 AND-001）と IR（Infrared）フィルタ（シ グマ光機 ECM-500）の 2 種類を使用した。ND フィルタは, 400 700nm における平均透過率 $(0.1 \%)$ に対して近赤外波長域 （700nm 1,200nm）の透過率が相対的に高くなっている。そこで, 近赤外波長域を吸収する IR フィルタを重ねて装着することで, 図 4 に示すように，スミアやゴーストを抑え，輝度の測定レンジを引き 上げることができた。

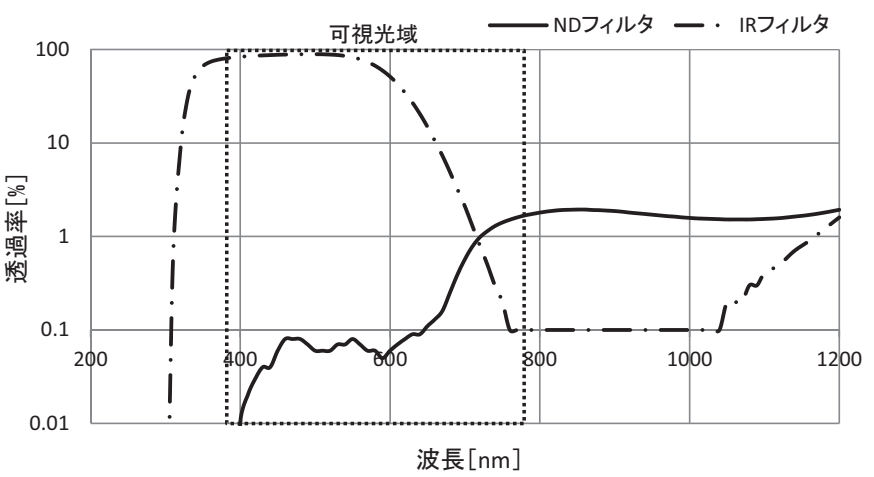

図 $3 \mathrm{ND} \cdot \mathrm{IR}$ フィルタの分光透過率 11) 12) 


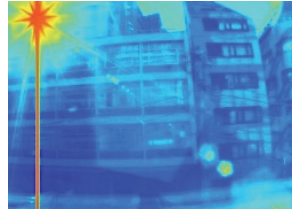

(a)フィルタなし

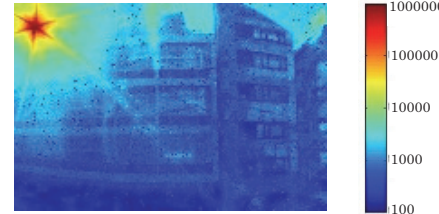

(b) ND・IR フィルタあり $\left[\mathrm{c} d / \mathrm{m}^{2}\right]$
図 $4 \mathrm{ND} \cdot \mathrm{IR}$ フィルタの有無による輝度画像の比較

\section{2 輝度コントラストを利用した検出方法}

前章の方法によって生成した輝度画像から，直射光や反射光の有 無を判定する方法を考える。中村によって提案された輝度コントラ スト（C 值）を算出するフィルタ（Nフィルタ） ${ }^{13)}$ は, 複雑な輝度 分布を持つ実空間の中で対象物と背景との輝度コントラストを定量 的に評価する手法である。具体的には，コントラスト・プロファイ ル法と呼ばれるもので, 輝度画像に対して Nフィルタを使用した対 数輝度の重みづけ加算によって求められ，特定のサイズのコントラ ストを抽出することが可能である。また，Nフィルタと同サイズの 平均化フィルタによるフィルタリングは, 特定サイズにおける対数 輝度平均（A 值）を算出でき， $\mathrm{C}$ 值と $\mathrm{A}$ 值を用いることで，輝度画 像内の特定サイズの高い輝度コントラストを持つエリアを検出し, そのエリアの輝度対比を定量的に評価することができる ${ }^{14)}$

以上から, 輝度画像の中から, 直射光や強い反射光が持つ局所的 な高輝度部を検出する方法として， C 值と $\mathrm{A}$ 值が利用できる可能性 があると考えた。

\section{3 判定閾値の検討}

$\mathrm{C}$ 值と $\mathrm{A}$ 值を基に, 直射光や強い反射光を検出することができる 判定閾值を検討寸る。制御の高速化のために, 輝度画像の生成は単 一のシャッタースピードで撮影（簡易測定）した画像を基に行う。 図 5 にシャッタースピード別の輝度画像と通常測定の輝度画像を示 す。いずれも直射光と建物ガラス面の反射光を映した画像である。 シャッタースピードが速い場合, 輝度の測定下限值が大きくなり, 下限值以下の輝度が全てゼロとなるため $\mathrm{A}$ 值算出に誤差が生じるこ とを考慮して, 今回, 輝度測定範囲が 18,000 9,200,000 cd $/ \mathrm{m}^{2}$ とな るシャッタースピード $1 / 200$ 秒とした。

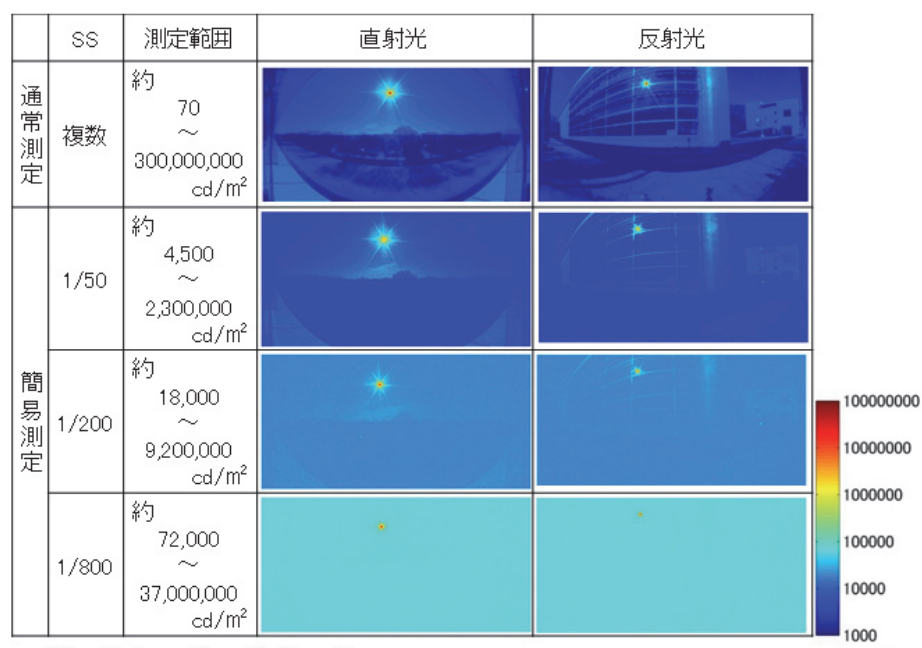

SS : シャッタースピード $\left[\mathrm{cd} / \mathrm{m}^{2}\right]$

図 5 シャッタースピード別の輝度画像
太陽のサイズはおよそ 0.5degree であるが，フレアの影響などで 大きめに写ることを考慮し，N フィルタの検出サイズは， 1.061 degree と決定した。Nフィルタを用いる際，検出周波数を fo とす ると，検出サイズは $2 /(\pi *$ fo $)$ で表され，検出サイズ 1.061 degree の場合，foは，0.6cycle/degree となる。また，今回用いた CCD カメラは 1 画素あたり 0.1degree の解像度のため, 1.061 degree は 10.61 画素となる。

$\mathrm{C}$ 值と $\mathrm{A}$ 值の判定閾值の決定は, 図 6 に示す 5 種類の検証画像に 対する評価によって行う。 5 種類の画像とは, (1)直射日光の写る画 像, (2)建物の強い反射光の写る画像, (3)夕陽の写る画像, (4)直射光 と反射光が同時に確認できる画像，(5)太陽の見えない晴天日の画像 であり，実用上想定されるケースを用いた。また，表 2 にはそれぞ れのケースにおける, $\mathrm{C}$ 值と $\mathrm{A}$ 值をシャッタースピード毎に算出し た結果を示す。この結果から,シャッタースピード $1 / 200$ において, $\mathrm{C}$ 值：0.4，A 值： 4.5 をいずれも超える場合が，直射光や眩しい反 射光を検出できる判定閾值となる可能性を示した。

この遮光要否判定方法について, その実用性を確認するために, 実際のオフィスにて実証実験を行った。

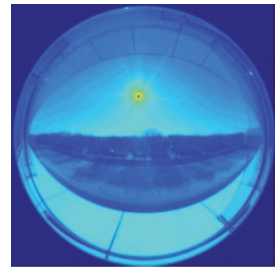

(1)直射光

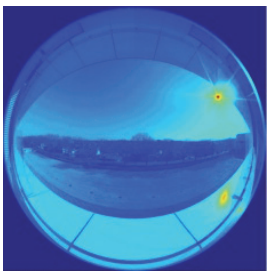

(4)直射光+反射光

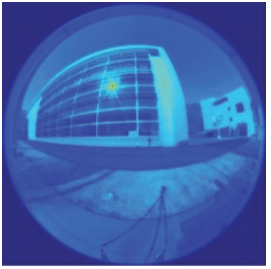

(2)反射光

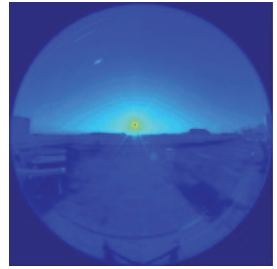

(3)夕陽

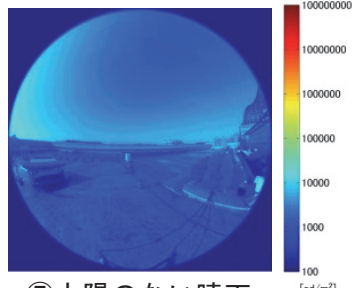

(5)太陽のない晴天

図 6 検証画像（通常測定）

表 2 検証画像におけるシャッタースピード別 C 值・A 值

\begin{tabular}{|c|c|c|c|c|c|c|c|c|c|c|}
\hline & \multicolumn{2}{|c|}{ (1)直射光 } & \multicolumn{2}{|c|}{ (2)反射光 } & \multicolumn{2}{|c|}{ (3)夕陽 } & \multicolumn{2}{|c|}{ (4)直射 + 反射光 } & \multicolumn{2}{|c|}{ (5)太陽のない晴天 } \\
\hline SS & C值 & A値 & C値 & A值 & C値 & A値 & C値 & A値 & C値 & A值 \\
\hline $1 / 6400$ & 1.2072 & 99 & 1.4794 & 5. & 1.4726 & 9585 & 1.2644 & 2359 & 0.0166 & 5.768 \\
\hline $1 / 3200$ & 1.0875 & 6 & 1.5315 & 5. & 1.0223 & 56 & 1.14 & & 08 & 468 \\
\hline $1 / 1600$ & 0.9344 & 5.9763 & 1.3155 & 5.5251 & 1.3437 & 5.3278 & 0.8955 & 6.0711 & 0.0110 & 5.168 \\
\hline $1 / 800$ & 0.7769 & 5.94 & 1.1362 & & 1.3214 & & 0.6 & & & .864 \\
\hline $1 / 400$ & 0.6019 & 5.9212 & 0.9954 & 5.2993 & 1.0815 & 5.0987 & 0.5473 & 6.0366 & 0.01 & 4.566 \\
\hline $1 / 200$ & 0.4782 & 5.8709 & 0.7839 & 5.2683 & 0.9528 & 5.0716 & 0.4108 & 6.0060 & 0.0232 & 4.265 \\
\hline $1 / 100$ & 0.3528 & 5.7955 & 0.6216 & 5.2479 & 0.6944 & 5.2000 & 0.3281 & 5.9314 & 0.0260 & 3.9691 \\
\hline $1 / 50$ & 0.2819 & 5.6934 & 0.4833 & 5.2294 & 0.5345 & 5.1883 & 0.2494 & 5.7955 & 0.0332 & 3.6755 \\
\hline $1 / 25$ & 0.2563 & 5.5159 & 0.3601 & 5.1956 & 0.2914 & 5.2423 & 0.2198 & 5.6268 & 0.0510 & 3.4259 \\
\hline $2 / 25$ & 0.2498 & 5.2879 & 0.2710 & 5.0932 & 0.2272 & 5.1794 & 0.1039 & 5.4691 & 0.0600 & 3.2828 \\
\hline $4 / 25$ & 0.2172 & 5.0393 & 0.7319 & 4.1180 & 0.1864 & 5.0364 & 0.2813 & .8917 & 0.0599 & 3.2585 \\
\hline $8 / 25$ & 1.0987 & 3.2340 & 0.0727 & 3.5263 & 0.1382 & 4.8606 & 0.4613 & 4.3832 & 0.0407 & 3.3054 \\
\hline $16 / 25$ & $\mathrm{NaN}$ & & 0.6605 & 3.46 & 0.1111 & 4.6308 & & $\mathrm{NaN}$ & 0.0560 & 3.3342 \\
\hline $32 / 25$ & $\mathrm{NaN}$ & $\mathrm{NaN}$ & 0.3687 & 3.9609 & 0.0599 & 3.1095 & $\mathrm{NaN}$ & $\mathrm{NaN}$ & 0.0595 & 3.3296 \\
\hline
\end{tabular}
C 值 $\geqq 0.4 \quad$ A 値 $\geqq 4.5$

\section{4. 輝度画像を利用した遮光要否判定の実証実験}

\section{1 実証実験施設の概要}

実証実験を実施した F ビルは，東京都千代田区に建設されたオフ 
イスビルであり, 図 7 に 2 階平面図, 図 8 に断面図を示す。執務室 の南西面と北西面にはフルハイトの空が配置されており, 直射光の ほか周辺建物の影や反射光も入射する環境にある。図 9 , 図 10 に各 空面からの眺望の様子を示す。この画像は, 前章で記した 2 種類の フィルタを装着した CCD カメラで撮影したものである。カメラは, 各空面の中央部にブラインドと空との間に外向きに設置した。取り 付け高さは床面より $2,300 \mathrm{~mm}$ とした（図 8)。空ガラスは, 可視光 の透過率が $74.1 \%$ を有した高遮熱の Low-E 複層ガラス（Low-E $8 \mathrm{~mm}+$ 空気層 $12 \mathrm{~mm}$ +フロート $8 \mathrm{~mm}$ ）を使用した。各空には 117 段階に角度を変更できる電動ブラインドを設置しており, グループ 毎に制御が可能である。

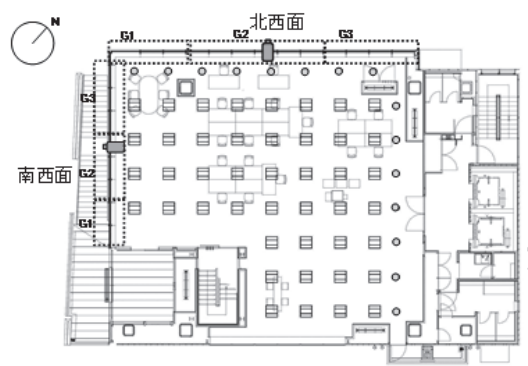

曰 $\operatorname{COD}$ 力八 ○ダウンライト

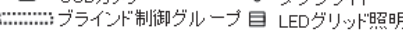

図 7 実証施設の平面図

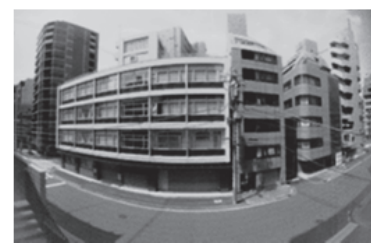

図 9 南西面空からの眺望

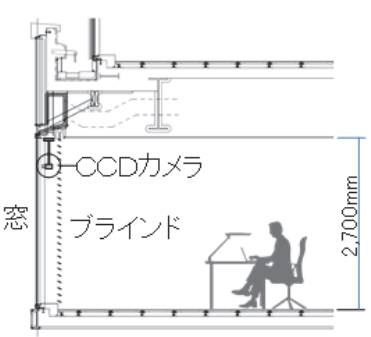

図 8 南西面窓断面図

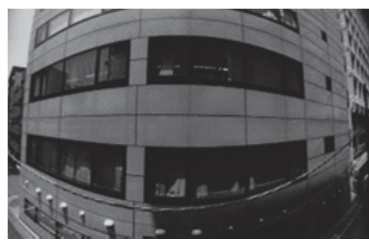

図 10 北西面窓からの眺望

\section{2 輝度コントラストによる判定実験と結果}

2015 年 3 月 12 日に南西面, 北西面の CCD カメラによって測定 した通常測定の輝度画像を図 11 に示す。それぞれ，目視によって， 「直射光あり」, 「反射光あり」, 「直射光・反射光なし」と確認された 状態の画像である。同時刻に $1 / 200$ 秒の単一シャッタースピードで 測定した輝度画像を基に輝度コントラストを用いて, 直射光, 反射 光の有無を評価した。結果を図 12 に示す。

実証実験の結果, 直射光, 反射光のある簡易測定輝度画像におい て, 前章で提案した判定の閾值（C 值： 0.4, A 值 : 4.5) をいずれも 超えていることから, 輝度コントラストを用いて, 直射光や反射光 を検出できることが示された。

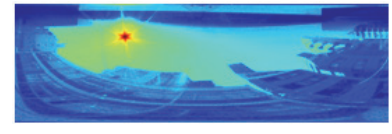

(a) 直射光あり

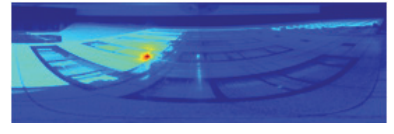

(b) 反射光あり
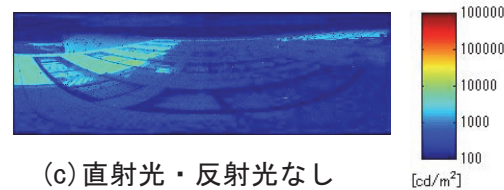

(c) 直射光 · 反射光なし

図 11 輝度画像（通常測定）

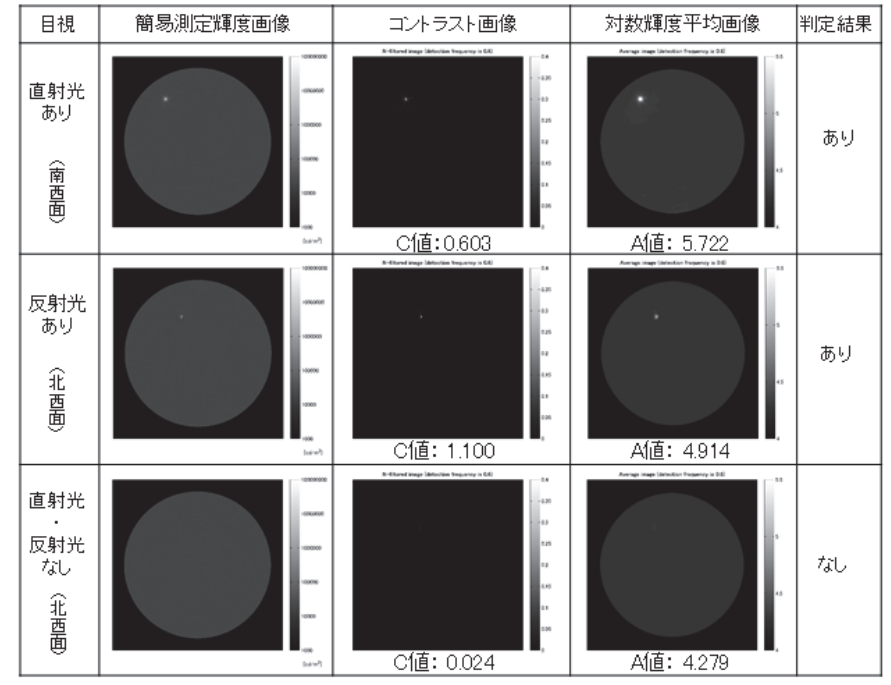

図 12 輝度コントラスト評価結果

\section{3 遮光要否判定制御の実証実験}

この判定方法を備えた自動ブラインド制御システムを Fビルに構 築し，同施設において自動制御の実証実験を行った。

図 13 にブラインド制御フローを示す。

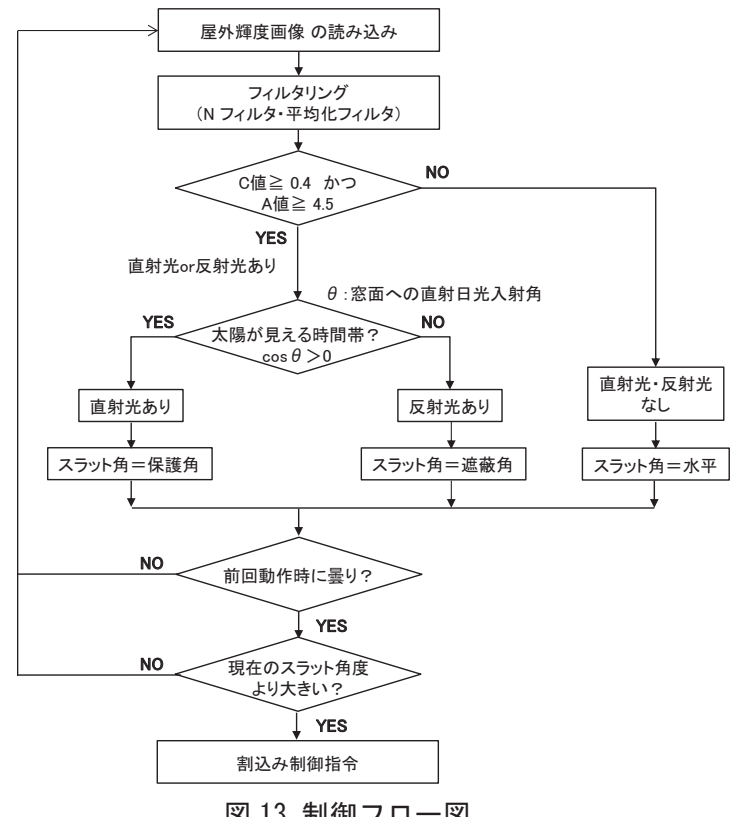

屋外輝度画像から輝度コントラストによって, 直射光または反射 光が存在することを判断する。直射光と反射光の判別は，空が面す る方位から空面に太陽が見える時間帯は, 直射光と判断し, 見えな い時間帯での検出は，反射光と判断することとした。

ブラインドのスラット角は, 直射光・反射光共に検出されない場 合, 水平 (0 度) に保たれる。直射光が検出された場合, スラット 角は保護角以上となる。スラットは, 室内側への内倒し（スラット 角がマイナス值をとる）も可能であり，保護角の範囲内で-20 度を 制限として制御される。反射光が検出された場合, 遮光角として F ビルにおいて設定した 30 度に制御され, 室内一反射光の入射を防 ぐ。急な入射に対応できるように，これらの制御は前回の遮光判定 
において直射光 ・ 反射光が共になく, 今回の判定で検出された場合 に, ブラインドを即座に制御できるように割込みの指令を発する。 2016 年 7 月 29 日（晴天日）に, 遮光要否判定の精度を確認する ため, 自動ブラインド制御と直射光, 反射光の有無の目視判定を並 行して行った。また，2017 年 1 月 13 日（晴天日）及び 14 日（薄曇 り日) には, 薄曇り時の判定精度を確認するため, 同様の実験を行 った。目視判定は, 筆者自身が 5 分おきに輝度測定用 CCD カメラ 下方部から天空を見上げた状態で行い, 太陽の輪郭が確認でき, か つ, 足元に陰影が発生していることを判定閾值とした。輝度測定用 CCD カメラの下方 $200 \mathrm{~mm}$ の位置に, 鉛直面外向きの照度計を設置 し, 空面の日照状態を計測した。また, 屋外の気象状態を把握する ために, 建物屋上に照度計を設置し, 水平面全天照度を測定した。

\section{4 実証実験の結果}

2016 年 7 月 29 日（晴天日）における実験結果を図 14〜図 19 に 示す。図 14 に示寸水平面全天照度の時刻別推移から, 当日は終日 量りのない晴天下での実験であった。図 15 , 図 17 は南西面, 北西 面での遮光要否判定結果とスラットの制御角度及び保護角の推移を 示す。判定結果は, 「直射光あり」,「反射光あり」, 「直射光・反射光 なし」のいずれかを時刻毎にプロットしている。輝度コントラスト を用いて制御システムが判断した結果を@印で, 目視判定した結果 を〉印で示した。また, スラット角の制御結果と空面における計算 上の保護角をそれぞれ実線と破線で示した。図 16, 図 18 は, 南西 面, 北西面での遮光判定結果と空面鉛直面照度の推移を示す。図 19 に図 16 及び図 18 の図中に明示した 4 時刻について通常測定の輝度 画像と同時刻の鉛直面照度を示す。

図 15 に示寸通り, 当日, 南西面においては, 11 時 25 分から 16 時 15 分まで直射光が入射する時間帯であり, 終日を通して制御シ ステムの遮光判定結果と目視判定結果は, ほぼ合致していた。太陽 が周辺建物の背後に部分的に隠れる 16 時 15 分に, 目視との不一致 が見られたが, 直後の 16 時 20 分には太陽が周辺建物の背後にまわ り, 空面に直射光が当たらなくなったため, いずれの判定も「直射 光なし」となった。図 19(a)及び(b)にその様子を示寸輝度画像と鉛 直面照度を示す。図 15 に示寸スラット角は, 14 時 40 分頃から, 保護角が-20 度を超えるため, 以降ブラインドは保護角で制御され た。 16 時 15 分には最大 8 度まで傾斜し, 16 時 20 分以降, スラッ 卜角が水平になる様子が確認できた。この時, 全天照度に大きな変 化は見られないが, 南西面の空面照度が急激に減少したことから, 空面に直射光が当たらなくなったことが確認できた。

図 17 に示すように, 北西面は 11 時 5 分より 12 時 10 分頃まで断 続的に反射光が検出された。また, 13 時 40 分以降, 直射光が検出 され, 14 時 22 分以降, 直射光 - 反射光共に検出されなくなった。 図 19(c)及び図 19(d)に反射光検出時及び直射光検出時の輝度画像と 鉛直面照度を示す。いずれも, 局所的な高輝度部分が検出できてい ることが確認できた。

制御システムの遮光判定結果と目視判定結果は, 11 時 5 分, 11 時 15 分, 11 時 20 分及び 12 時 10 分の 4 度を除いて, 全て合致し ていた。図 18 に示寸ように 11 時 30 分頃の北西面の空面照度は, 隣棟の影響を受け, 大きな上下の変動を繰り返した。この変動は, 太陽光を反射する部位の違いによって起こるものと考えられる。空
ガラスに太陽光が反射した場合に, 強い反射光が現れ, 鉛直面照度 が高くなる。一方，金属外装（アルミカーテンウォール）に反射し た場合は，相対的に低くなっている。しかし，いずれも，高輝度部 分が検出されたため,「反射光あり」と判断した

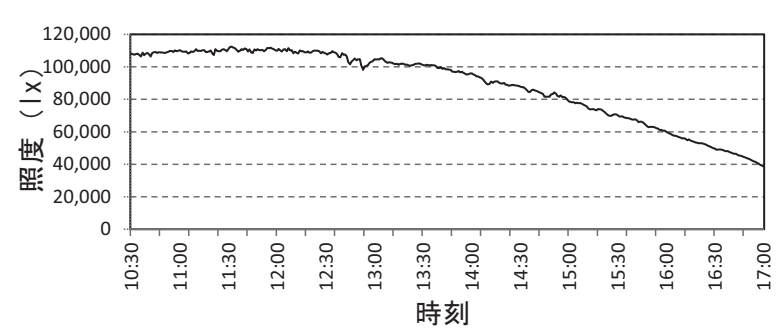

図 14 水平面全天照度

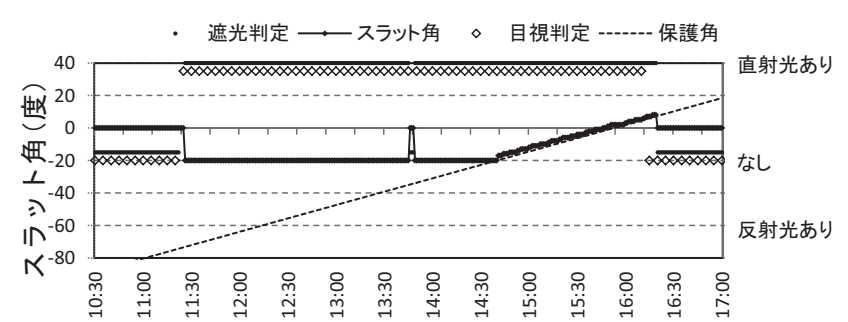

時刻

図 15 判定結果の比較とスラット角の推移（南西面）

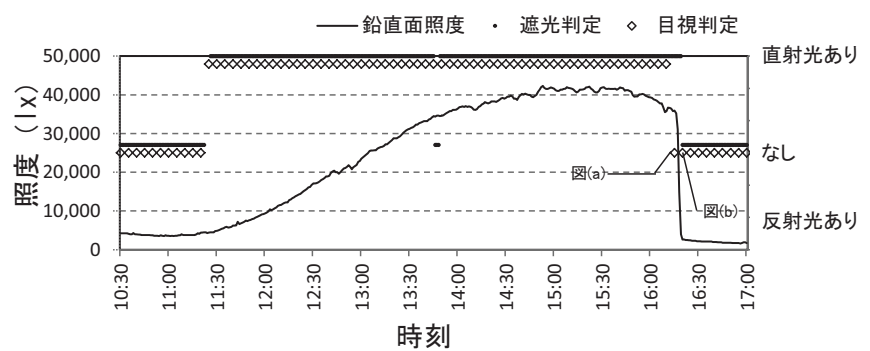

図 16 判定結果の比較と鉛直面照度の推移（南西面）

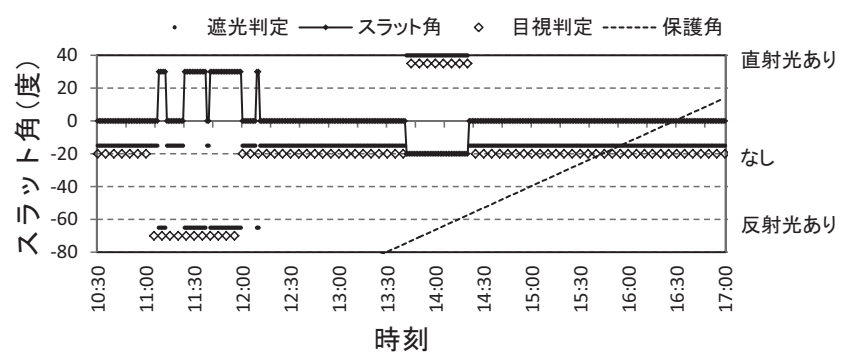

図 17 判定結果の比較とスラット角の推移（北西面）

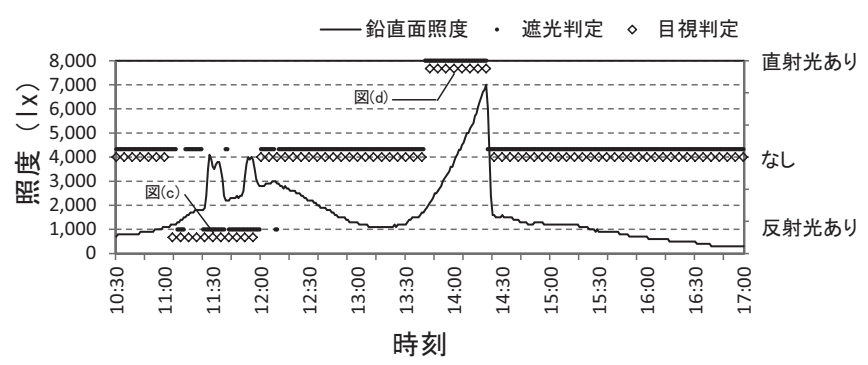

図 18 判定結果の比較と鉛直面照度の推移（北西面） 


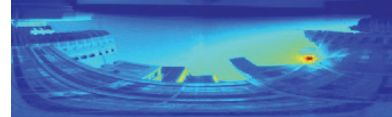

鉛直面照度 $35,9001 x$

(a) 16 時 15 分（南西面） (O)

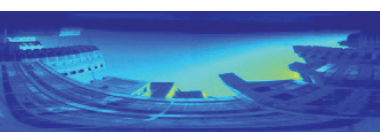

鉛直面照度 $2,6001 x$

(b) 16 時 20 分（南西面） $(x)$

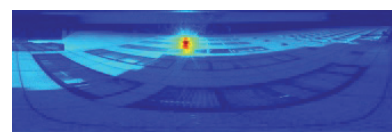

鉛直面照度 $3,6001 x$

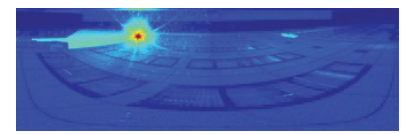

鉛直面照度 $3,8001 x$

(d) 14 時 00 分（北西面） (O)

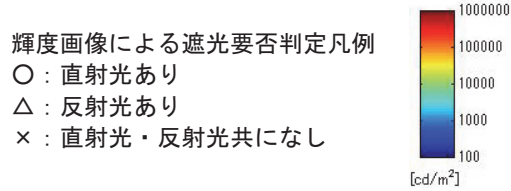

図 19 輝度画像と画像による遮光要否判定結果

次に, 太陽が雲に隠れるような薄曇りの日において, 遮光要否判 定の実用性を検証した。図 20 図 23 に, 2017 年 1 月 13 日及び 1 月 14 日に実施した南西面空での実証結果を示す。当日, 南西面空 に直射光が当たる時間帯は, 10 時 10 分〜 10 時 50 分と 12 時 27 分 〜 12 時 53 分であり, この時間帯以外は, 周辺建物の影になる。測 定は，この時間帯を含む 10 時から 13 時まで行った。

図 20 は，屋上に設置した照度計で測定した水平面全天照度を示 す。13 日は安定した晴天日であった。一方，14 日は薄日の射す是 りから 12 時以降, 曇天に移り変わっていった。図 21 , 図 22 は前 述の実験と同様に, ブラインド制御システムの遮光判定結果と目視 による判定結果及び空面での鉛直面照度の時刻別推移を示す。1 13 日, 空面に直射光が当たるすべての時間帯において, 遮光判定, 目視判 定ともに「直射光あり」と判定した。空面照度も 10 時台では 7,000lx から 17,000lx，12 時台では 47,000lx を記録し, 周辺建物の影にな る時間帯の照度 $2,1001 \mathrm{x}$ に比べて高い值を示した。

一方， 14 日，10 時台においては「直射光あり」と「直射光・反 射光なし」の判定を繰り返した。図 $23(\mathrm{a})$ ，(b)に 10 時 25 分（直射 光・ 反射光なし）と 10 時 30 分（直射光あり）の輝度画像（通常測 定）と鉛直面照度をそれぞれ示す。雲の厚さの違いにより 10 時 25 分の画像には高輝度部分がなく「直射光・反射光なし」と判定し, 10 時 30 分の画像には局所的な高輝度部分が存在し，「直射光あり」 と判定した。また，その時の鉛直面照度も 4,200lx であり，10 時 雲に覆われ始めたため, 「直射光・反射光なし」の判定が続いた。ど ちらの時間帯においても, 遮光判定結果は目視判定と合致していた。 10 時台において, 空面照度は $4,000 \mathrm{~lx}$ 程度を境として, 上回る場 合に「直射光あり」, 下回る場合に「直射光・反射光なし」と判定さ れた。一方, 周辺建物の影になる 10 時 50 分以降においても, 空面 照度が 4,0001x を超える時間帯が発生していた。これは, 曇天時の 天空光の高まりによるものであり, 照度だけでは高輝度部の存在を 判別することができず, 遮光要否判定が難しいことを示唆している。 以上のことから, 今回提案した遮光要否判定方法は, 晴天日だけ でなく, 薄曇りのような日においても直射光の有無を判別できるこ 25 分時点の照度 $3,5001 \mathrm{x}$ よりも高い值を示した。12 時台は, 厚い
とが確認できた。この判定方法を利用した空面の日照状態に合わせ たブラインド制御によって，スラットの開放時間を拡大することが 可能となり，自然光の採光量や眺望性を増大寸ることができ, 照明 消費エネルギーの削減や快適性の向上に貢献できる可能性が示され た。

図 20 水平面全天照度

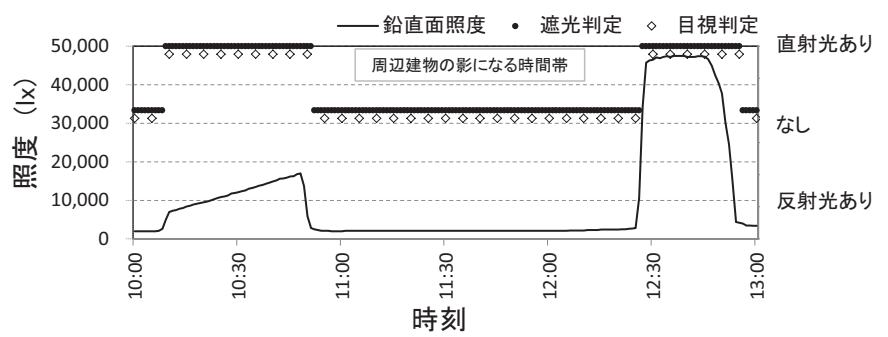

図 21 判定結果の比較と鉛直面照度の推移（1月 13 日）

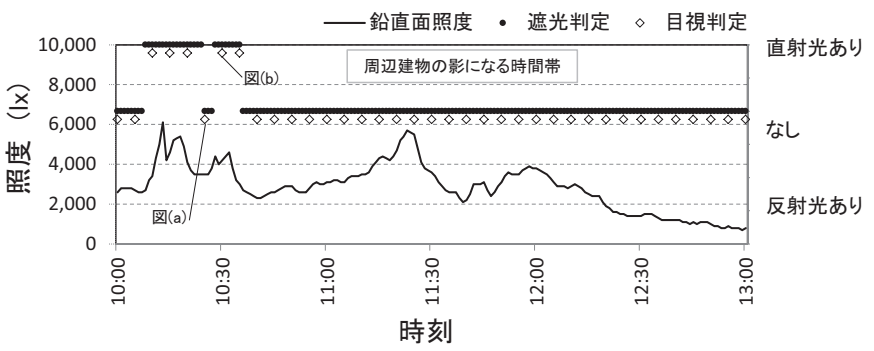

図 22 判定結果の比較と鉛直面照度の推移（1月 14 日）

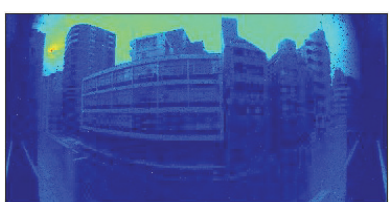

鉛直面照度 $3,5001 x$

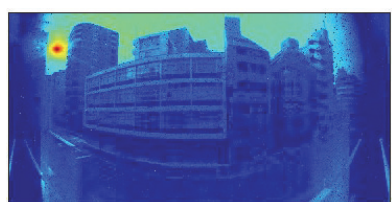

鉛直面照度 $4,2001 x$ (a) 10 時 25 分（南西面） ( $x$

(b) 10 時 30 分（南西面）(O)

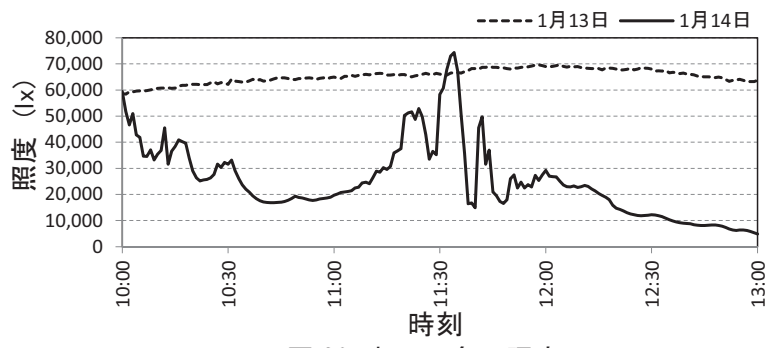

輝度画像による遮光要否判定凡例 O : 直射光あり

× : 直射光・反射光共になし

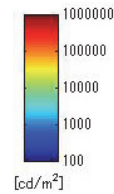

図 23 輝度画像と画像による遮光要否判定結果

\section{5. 結論}

本研究では, CCD カメラで生成した輝度画像を利用し, 高速で日 射遮光要否判定を行い適切にブラインドのスラット角度を制御する 方法について検討を行い，以下の知見を得た。

$1 ）$ 分光透過率の異なる 2 種類のフィルタを装着した魚眼レンズと CCD カメラによって, 直射日光や反射光を含む高い輝度を測定でき 
る可能性を示した。

2 ) 中村が提案した N フィルタと平均化フィルタによるフィルタリ ングによって得られる, 輝度コントラスト $(\mathrm{C}$ 值) と対数輝度平均 值（A 值）を利用して, 輝度画像から直射光や反射光を検出するこ とができた。

3 ) 制御の高速化のために, 単一シャッタースピード (1/200 秒) で撮影した CCD カメラの輝度画像を用いて, 直射光と反射光を検 出できる閾值（C 值 : 0.4, A 值 : 4.5) を求めることができた。

4) 検討した判定手法を実際に使用されているオフィスのブライン ド制御システムに適用し, 晴天日や曇天日などの違った天候条件下 においても直射光や周辺建物の反射光を検出することができ, 判定 手法の有用性と実用性が確認できた。

5 ) 空面毎に制御することによって, 自然採光の増大や眺望性の向 上に寄与できる可能性を示した。

6 ) 以上より, 本研究の成果は, 今後の精度の高いブラインド制御 方法の普及に向け，一助となり得る可能性を示した。

本報では, 輝度画像を基にグレアを発生する可能性のある直射光 や反射光を検出する方法を検討し, 側空を有するオフィスにおいて ブラインド制御実証実験を行った。ブラインドのスラット角度決定 には, 空面のグレア評価は不可欠であり, 輝度画像を利用したグレ ア評価について今後, 検討していく予定である。また, 同施設にお いてタスク・アンビエント照明のオフィスにとって適度な明るさ感 を確保するブラインドと照明の協調制御についても併せて検討して いく予定である。

本研究が目指すシステムはカメラ画像を使用するために, 最終的 に製品化されるまでには, コスト面などの課題も想定される。現在, CCD カメラや画像解析は様々な分野での応用が検討され, 今後とも 需要が高まる中で価格の低下も期待されている。また, 健康経営の 視点から仕事場の環境改善も注目されており, 自然光の享受は重要 な要素として位置づけられている。このような社会変化を見据えな がら引続き研究開発を進めていく所存である。

\section{謝 辞}

本研究は, 独立行政法人 新エネルギー・産業技術総合開発機構が 実施する「平成 24 年度戦略的省エネルギー技術革新プログラム」 の助成を受け実施したものである。

本研究のシステム開発のためご協力頂いた皆様に深甚の謝意を表 する。

\section{参考文献}

1) 望月悦子・村江行忠 : 空からの昼光に連動した照明制御の心理・生理的効 果に関する研究, 日本建築学会大会学術講演梗概集, 環境工学 I, pp. 501-504, 2014

2) 古賀靖子 : 光放射の非視覚的効果の定量化に関する標準化動向, 照明学会 誌, 99-1, pp. 28-31，2015

3)市原真希ほか：午前中の昼光照明が生理量及び知的生産性に与える影響の 検討その 1 , 実測概要と物理環境の測定結果, 日本建築学会大会学術講演 梗概集，環境工学 I ，pp. 1255-1256，2010

4) 伊藤大輔・岩田利枝・岩佐義久 ・佐々木真人・柳井崇 : 視環境評価に基づ くブラインド制御に関する研究, 空気調和・衛生工学会大会学術講演論文 集, pp. 1513-1516，2006.9

5) 本間睦朗・岩田利枝・川瀬貴晴 : 天空画像による自動ブラインド制御のた めの直射日光遮蔽要否判断, 日本建築学会環境系論文集, 第 660 号, pp. 125-130, 2011. 2
6)一ノ瀬雅之・井上隆・田宮有見子 : 気象の変動に追従するブラインドの自 動制御手法, 日本建築学会環境系論文集, 第 646 号, pp. 1339-1345, 2009. 12

7)日経アーキテクチュア (919), 46-50, 2010-02-08, 日経 BP 社

8) 岩田利枝・塚見史郎：CCD カメラの光環境計測への応用技術, 照明学会誌, 81-3, pp. 246-249, 1997

9) 伊藤大輔・岩田利枝・小野島一：CCD カメラを用いた輝度分布測定システ ムによる人工照明制御に関する研究, 日本建築学会大会学術講演梗概集, 環境 2, pp. 303-306, 2005

10) (株) ジェイエイアイコーポレーション : BM-500GE, カタログ

https://www. yumpu. com/en/document/view/25062902/cm-141-pmcl-cb-141 -pmcl (2016/8/8 閲覧)

11) シグマ光機(株)：AND-001 フィルタ透過率波長特性，カタログ，B68 https://www. global-optosigma. com/jp/Catalogs/gno/?from=page\&pnonam $\mathrm{e}=$ AND - S\&ccode $=W 3095 \&$ dcode $=W 3095-2 \&$ gnoname $=$ AND $-50 S-001 \quad （ 2016 / 8 / 8$ 閲覧）

12)シグマ光機(株)：ECM-50S-500フィルタ透過率波長特性，カタログ，B97 https://www. global-optosigma. com/jp/Catalogs/gno/?from=page\&pnonam $\mathrm{e}=\mathrm{CCF} \% 2 \mathrm{FECM} \& \mathrm{ccode}=W 3112 \&$ dcode $=\&$ gnoname $=\mathrm{ECM}-50 \mathrm{~S}-500 \quad(2016 / 8 / 8$ 閲覧

13) 中村芳樹：光環境における輝度の対比の定量的検討法, 照明学会誌, 84-8A, pp. 522-528, 2000

14) 高橋嶺ら : 輝度分布を持つ不快グレア源の定量的評価, 日本建築学会大会 学術講演梗概集, 環境工学 I, pp. 427-430, 2015

15) 小島義包ら : 明るさ感を向上させた省エネルギー照明システムに関する研 究その 6 , 側空採光オフィスにおける照明・ブラインド制御の概要, 日本 建築学会大会学術講演梗概集, 環境工学 I, pp. 401-402, 2015

16) 大木知佳子ら : 明るさ感を向上させた省エネルギー照明システムに関する 研究 その 7 側空採光オフィスにおる照明制御例, 日本建築学会大会学術 講演梗概集, 環境工学 I, pp. 403-404, 2015

17) 加藤洋子ら : 明るさ感を向上させた省エネルギー照明システムに関する研 究その 8 ブラインド制御の概要と遮光判定手法, 日本建築学会大会学術 講演梗概集, 環境工学 I, pp. 405-406, 2015

18) 矢部周子ら : 明るさ感を向上させた省エネルギー照明システムに関する研 究その 9 明るさ判定ロジック及び実物件への導入事例, 日本建築学会大 会学術講演梗概集, 環境工学 I, pp. 407-408, 2015

19) Yoshikane Kojima et al. : Light environment control system using brightness image, Proceedings $28^{\text {th }}$ CIE, pp.1137-1147, 2015 


\title{
STUDY ON EVALUATION METHOD OF SOLAR SHADING FOR BLIND CONTROL BASED ON LUMINANCE IMAGES
}

\author{
Yoshikane KOJIMA*, Yoshiki NAKAMURA**, Yoko KATO***, \\ Chikako OHKI****, Chikako YABE ${ }^{* * * * *}$ and Sueko KANAYA***** \\ * Obayashi Corporation, M. Eng. \\ ** Prof., Tokyo Institute of Technology, Dr. Eng. \\ *** Grad. Student, Dept. of Architecture and Building Engineering, School of Environment and Society, Tokyo Institute of Technology, M. Eng. \\ **** Obayashi Corporation \\ ***** Obayashi Corporation, M. Eng. \\ $* * * * *$ Visual Technology Laboratory Inc., Dr. Eng.
}

Japan establishes the goals to realize ZEBs (net zero energy building) in average newly constructed public and private buildings by 2030 . The primary energy consumption of the illumination in the office building accounts for around $20 \%$ of the whole building. Therefore, thorough saving energy is demanded for illumination to achieve ZEB.

The effective method for the saving energy of illumination is the use of day light. The natural light of the workplace in office building is generally adopted through a side window. Venetian blinds are installed in the window for solar shading. In the automatic blind control system installed at the large scale building, slats of blind are uniformly controlled by illuminance censor fixed on the top of the building. This is not able to detect direct sunlight and the light from adjacency building at the side window.

We devised technique to detect not only the direct sunlight but also the dazzling borrowed light from adjacency building based on a luminance image provided with a CCD camera for the purpose of the development of the higher precise judgment of solar shading. We built the system which could perform shading immediately at the time of the detection and introduced it into the actual work office.

As a result of proof experiment, the following knowledge was provided in conclusion.

1) A method to measure high range of luminance including direct sun light and the borrowed light by a fisheye lens and the CCD camera which attached two kinds of filters which varied in the spectral transmittance was showed.

2) Using luminance contrast (C value) and the logarithm luminance mean (A value) to be provided by $\mathrm{N}$ filter and the averaging filter developed by Nakamura, detect direct rays of the sun and borrowed light can be identified in luminance image.

3) The threshold of $\mathrm{C}$ value: 0.4 and A value: 4.5 that can detect direct rays of the sun and borrowed light using the luminance image measured at single shutter speed of 1/200 second by the CCD camera are identified for speedup of the control.

4) The evaluation method proposed in this study applied to blind control system in actual workplace could detect direct sun light and borrowed light of neighboring buildings with high precision and was able to confirm the usefulness and effectiveness.

5) The possibility that could contribute to increase of the day lighting and view-related improvement by controlling every window is showed

6) The result of this study showed the possibility that could help it toward the spread of blind control systems with higher precision. 